\title{
Effect of Monosodium Glutamate on Apoptosis and Bcl-2/Bax Protein Level in Rat Thymocyte Culture
}

\author{
V. PAVLOVIĆ ${ }^{1}$, S. CEKIĆ ${ }^{1}$, G. KOCIĆ ${ }^{2}$, D. SOKOLOVIĆ 2 , V. ŽIVKOVIĆ 3 \\ ${ }^{1}$ Institute of Physiology, Institute of Biochemistry, ${ }^{3}$ Institute of Pathology, Medical Faculty, \\ University of Nis, Serbia
}

Received July 11, 2006

Accepted September 4, 2006

On-line available December 19, 2006

\begin{abstract}
Summary
Monosodium glutamate (MSG), the sodium salt of glutamate, is commonly used as a flavor enhancer in modern nutrition. Recent studies have shown the existence of glutamate receptors on lymphocytes, thymocytes and thymic stromal cells. In this study, we evaluated the in vitro effect of different MSG concentrations on rat thymocyte apoptosis and expression of two apoptosis-related proteins, Bcl-2 and Bax. Rat thymocytes, obtained from male Wistar rats, were exposed to increasing concentrations of MSG (ranging from $1 \mathrm{mM}$ to $100 \mathrm{mM}$ ) for $24 \mathrm{~h}$. Apoptosis was detected using the Annexin V-FITC/PI apoptosis detection kit and cells were analyzed using a flow cytometer. Expression of Bcl-2 and Bax proteins were determined with flow cytometry using respective monoclonal antibodies. Exposure to MSG resulted in a dose-dependent decrease in cell survival (as determined by trypan blue exclusion method). Annexin VFITC/PI also confirmed that MSG increased, in a dose-dependent manner, apoptotic cell death in rat thymocyte cultures. MSG treatment induced downregulation of Bcl-2 protein, while Bax protein levels were not significantly changed. Our data showed that MSG significantly modulates thymocyte apoptosis rate in cultures. The temporal profile of Bcl-2 and Bax expression after MSG treatment suggests that downregulation of Bcl-2 protein and the resulting change of Bcl-2/Bax protein ratio may be an important event in thymocyte apoptosis triggered by MSG.
\end{abstract}

Key words

Monosodium glutamate $\bullet$ Thymocytes $\bullet$ Apoptosis $\bullet$ Bcl-2 $\bullet$ Bax

\section{Introduction}

Glutamate is an excitatory neurotransmitter in the central nervous system of mammals, where it acts through ionotropic (iGluR) and metabotropic (mGluR) glutamate receptors. iGluR (NMDA, AMPA and kainate receptors) form ion channels permeable to particular cations, while mGluR activate intracellular signaling mechanisms via several associated G proteins (Storto et al. 2000). On the basis of their sequence homology, pharmacological characteristics and second-messenger coupling, mGluR have been classified into Group I (mGlu1 and mGlu5 receptors), Group II (mGlu2 and mGlu3 receptors) and Group III (mGlu4, mGlu6, mGlu7 and mGlu8 receptors) (Hinoi et al. 2004). Recent data showed the expression of glutamate receptors on different non-neuronal cells (Gill and Pulido 2001, Skerry and Genever 2001, Hinoi et al. 2004). Among non-neuronal 
cells, iGluR and mGluR have been identified in human lymphocytes (Lombardi et al. 2001, Ganor et al. 2003, Pacheco et al. 2004). Further studies indicated that mGluR also exist in mice (Storto et al. 2000) and rat thymocytes (Rezzani et al. 2003). Glutamate increased intracellular concentration of calcium ions in human (Lombardi et al. 2004) and rodent lymphocytes (Boldyrev et al. 2004). However, a precise function of glutamate receptors on lymphocytes is largely unknown.

The neurotoxicity, induced by excessive activation of glutamate receptors, has been associated with diverse neurodegenerative diseases (Gill et al. 2000) as well as with the excitotoxicity after ingestion of glutamate in the form of monosodium glutamate (MSG) when consumed in high concentrations (Choudhary et al. 1996). The exact mechanism of neuronal cell death, induced by excitotoxins, still remains unknown. However, there is accumulating evidence suggesting that glutamate-induced toxicity can be mediated through necrosis and apoptosis (Martin et al. 2000, Ankarcrona et al. 1998). Consequences of glutamate release and distribution patterns of its receptors have been mainly studied in the central nervous system but also in several other organs (Storto et al. 2001, Gill et al. 1999) but not in thymus. Therefore, the current study was designed to examine the in vitro effect of MSG on rat thymocyte apoptosis and to answer the question whether this process involves changes in Bcl-2 and Bax protein level.

\section{Methods}

Animals

Experiments were performed on adult male Wistar rats (120-140 g), 8-10 weeks old, bred at the Vivarium of the Institute of Biomedical Research, Medical Faculty, Nis, under conventional laboratory conditions. The experimental animals were treated in accordance with national animal protection guidelines.

\section{Materials}

Culture medium (CM) was prepared using RPMI 1640 (Sigma, St Louis, Mo., USA), according to the manufacturer's instructions. $\mathrm{CM}$ containing $25 \mathrm{mM}$ HEPES, $2 \mathrm{mM}$ glutamine, penicillin (100 U/ml), streptomycin $(100 \mu \mathrm{g} / \mathrm{ml})$ and $10 \%$ fetal calf serum (FCS). Monosodium glutamate (MSG) was obtained from Fluka Chemika AG (Buchs, Switzerland).

The following monoclonal antibodies were purchased from Immunotech (Marseille, France): mouse anti-rat Bcl-2 (clone 5D4) and goat $\mathrm{F}\left(\mathrm{ab}^{\prime}\right)_{2}$ phycoerythrin (PE)-conjugated anti-mouse IgG $(\mathrm{H}+\mathrm{L})$. Mouse anti-rat Bax (clone 6A7) monoclonal antibody was obtained from Sigma (St Louis, MO, USA).

\section{Preparation of thymocytes and cell culture}

The thymus was extirpated using sterile technique and placed in CM/10\% FCS. Thymocytes were released by teasing thymus through a steel mesh. Cell suspensions were filtered through sterile nylon filter to remove stroma and then the cells were washed twice with $\mathrm{CM} / 10 \%$ FCS. Thymocytes were counted and adjusted to a density of $1 \times 10^{7}$ cells $/ \mathrm{ml}$. Cells were cultured in 96-well flat-bottom plates (Sarstedt, Newton, USA), containing a $100 \mu \mathrm{l}$ of cell suspension $\left(1 \times 10^{6}\right.$ cells) in each well with increasing concentrations of MSG, ranging from $1 \mathrm{mM}$ to $100 \mathrm{mM}$. All cultures were treated in triplicates. The thymocytes were cultured for $24 \mathrm{~h}$ in an incubator (Assab, Sweden) at $37{ }^{\circ} \mathrm{C}$ in an atmosphere of $95 \%$ air and $5 \%$ carbon dioxide.

\section{Determination of cell viability}

Thymocytes were cultivated in 96-well flatbottom plates $\left(1 \times 10^{6}\right.$ cells/well; $\left.200 \mu \mathrm{l}\right)$ with increasing concentration of MSG (1-100 mM). Cell viability was evaluated after $24 \mathrm{~h}$ incubation by the trypan blue exclusion method. The percentages of viable cells were calculated on the basis of total number of cells before cultivation.

\section{Detection of apoptosis (flow cytometry)}

Detection of apoptosis by flow cytometry was performed using the Annexin V-FITC/Propidium iodide (PI) apoptosis detection kit (Immunotech, Marseille, France). The staining was performed according to the producer's manual. Five thousand cells per sample were analyzed using an Epics ${ }^{\circledR} \mathrm{XL}$ flow cytometer (Coulter, Krefeld, Germany). Annexin $\mathrm{V}$ is a $\mathrm{Ca}^{2+}$-dependent phospholipids-binding protein that has a high affinity for phosphatidylserine (PS), translocated from the inner leaflet of the plasma membrane to the outer leaflet in apoptotic cells (Vermes et al. 1995). Annexin V-FITC is a sensitive probe for identifying cells that are undergoing apoptosis, because PS exposure occurs early in the apoptotic process (Koopman et al. 1994). PI is a nonspecific DNA dye that is excluded from living cells with intact plasma membranes but incorporated into nonviable cells (Eray et al. 2001). When normal thymocytes are cultured in vitro, they undergo spontaneous apoptosis and 
Table 1. In vitro effect of MSG on rat thymocyte apoptosis and viability.

\begin{tabular}{|c|c|c|c|c|}
\hline \multirow[t]{2}{*}{ Culture conditions } & \multicolumn{3}{|c|}{$\begin{array}{l}\text { Apoptosis } \\
\text { (flow cytometry) }\end{array}$} & \multirow{2}{*}{$\begin{array}{l}\text { Viability } \\
\text { (trypan blue exclusion) } \\
\text { Total }(\%)\end{array}$} \\
\hline & Total (\%) & Early (\%) & Late (\%) & \\
\hline Medium & $25.8 \pm 3.47$ & $22.3 \pm 3$ & $3.5 \pm 2.17$ & $67.4 \pm 4.2$ \\
\hline Medium+1 mM MSG & $41.6 \pm 7.6^{*}$ & $24.93 \pm 3.7$ & $16.7 \pm 4.9$ & $55.8 \pm 5.2 *$ \\
\hline Medium $+10 \mathrm{mM} M S G$ & $54.3 \pm 5.9 * *$ & $19.03 \pm 2.7$ & $35.3 \pm 7.6$ & $39.2 \pm 4.2 * *$ \\
\hline Medium +100 mM MSG & $64.6 \pm 5.5 * * *$ & $14.7 \pm 3.9$ & $50.2 \pm 5$ & $26.5 \pm 5.1 * * *$ \\
\hline
\end{tabular}

Thymocytes ( $1 \times 10^{6}$ cells/well) were cultivated for $24 \mathrm{~h}$ with increasing concentrations of MSG. Cell viability was determined by trypan blue exclusion method, whereas apoptosis was measured using flow cytometry as previously described. Total percentages of AnnexinFITC positive cells were considered as total percentage of apoptotic cells. Annexin-FITC +/PI - were cells in the early stage of apoptosis whereas Annexin-FITC +/PI + were cells in the late stage of apoptosis. Values are given as mean percentage \pm SD for three separate experiments. $* \mathrm{p}<0.05, * * \mathrm{p}<0.01, * * * \mathrm{p}<0.001$ compared to medium controls.

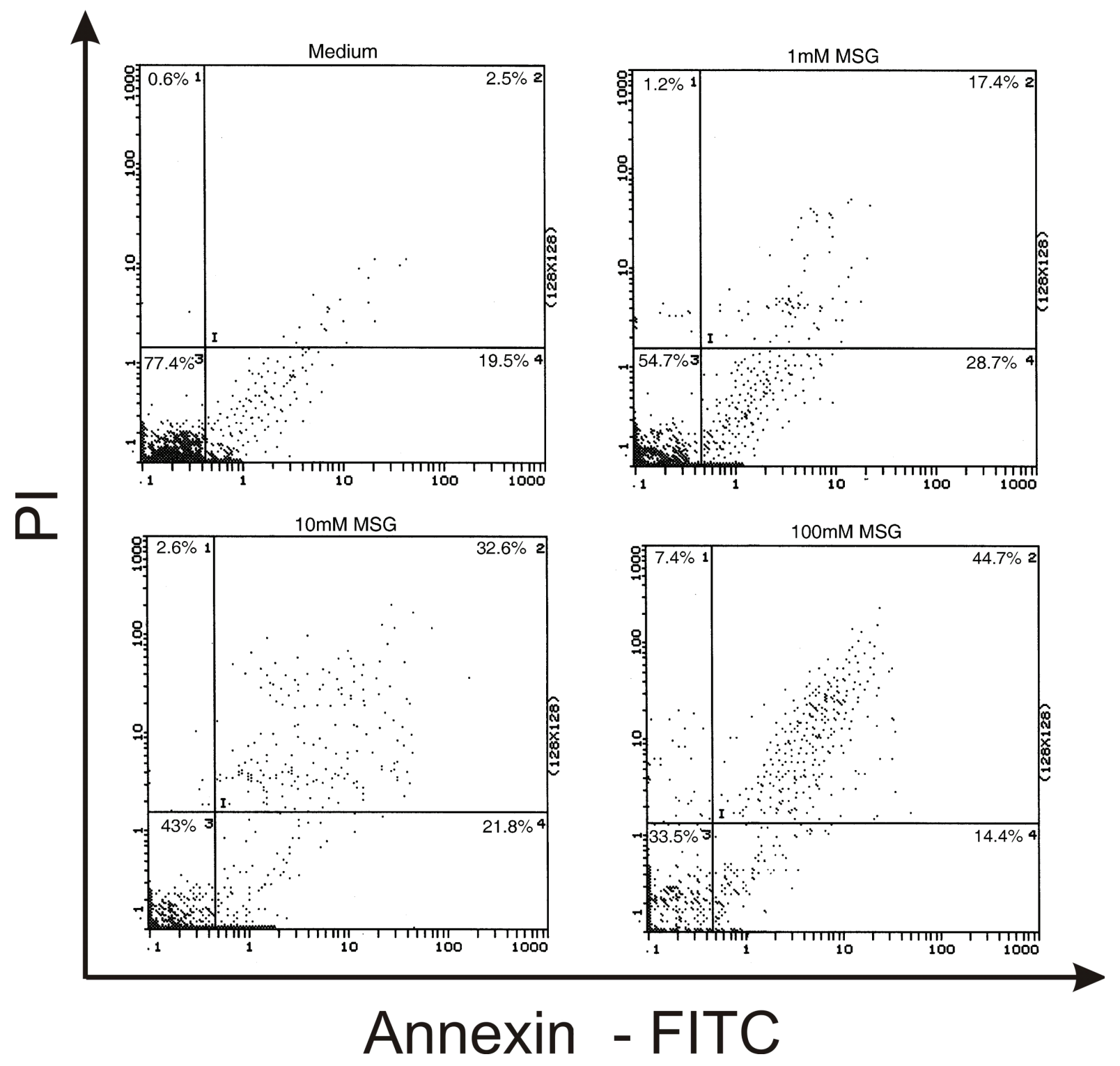

Fig. 1. Effect of MSG on rat thymocyte apoptosis (flow cytometric analysis). 
appear initially as Annexin V+/PI- cells. However, with increasing culture duration, the same cells appear as Annexin V+/PI+ cells (Okasha et al. 2001). Thus, as single positive populations are considered the early apoptotic (Annexin V+/PI-) or necrotic cells (Annexin $\mathrm{V}-/ \mathrm{PI}+$ ), whereas double positive (Annexin $\mathrm{V}+/ \mathrm{PI}+$ ) cells are thought to be in a late stage of apoptosis rather than in necrosis (Okasha et al. 2001, Vermes et al. 1995, Lecoeur et al. 2001).

\section{Flow cytometric evaluation of Bcl-2 and Bax levels}

The levels Bcl-2 and Bax were measured by flow cytometry as described previously (Antonella et al. 1992, Liu and Zhu 1999), with minor modifications. Briefly, thymocytes were cultivated in CM/10 \% FCS without or with different concentrations of MSG (ranging from $1 \mathrm{mM}$ to $100 \mathrm{mM}$ ) for $24 \mathrm{~h}$. Thereafter the cells were collected, washed twice with in PBS containing $5 \%$ FCS. Permeabilization of thymocytes was done using saponin-based permeabilization reagent IntraPrep ${ }^{\mathrm{TM}}$ (Immunotech, Marseille, France), according to the manufacturer instructions. Cells were incubated in the darkness for $45 \mathrm{~min}$ at room temperature with anti-rat Bcl-2 monoclonal antibody (final concentration $2 \mu \mathrm{g} / \mathrm{ml}$ ) and anti-rat Bax monoclonal antibody (final concentration $10 \mu \mathrm{g} / \mathrm{ml})$. After incubation, cells were washed twice in PBS containing $5 \%$ FCS and incubated in the darkness, at room temperature, for $30 \mathrm{~min}$ with PEconjugated anti-mouse IgG monoclonal antibody (diluted 1:100). Non-specific binding was detected by the control cells which were incubated with the secondary antibody (PE-conjugated anti-mouse $\mathrm{IgG}$ ) alone. Labeled cells were fixed in $4 \%$ formalin and analyzed (5000 analyzed cells/per sample) on a flow cytometer.

\section{Statistical analysis}

Results are presented as means $\pm \mathrm{SD}$ of three independent experiments or triplicate samples. Significant differences between the groups were analyzed using Student's t-test.

\section{Results}

\section{MSG induces cytotoxicity in rat thymocytes}

To investigate the dose response of MSG, thymocytes were cultured with increasing concentrations of MSG (1-100 mM) for $24 \mathrm{~h}$ and assayed for cell viability. Exposure to increasing concentrations of MSG resulted in a dose-dependent decrease in cell viability. A significant increase in cytotoxicity was detected following treatment with $1 \mathrm{mM}(\mathrm{p}<0.05), 10 \mathrm{mM}$ $(\mathrm{p}<0.01)$ and $100 \mathrm{mM}(\mathrm{p}<0.001) \mathrm{MSG}$ (Table 1$)$.

\section{Effect of MSG on apoptosis rate}

To examine whether MSG-induced cytotoxicity involves apoptosis, we evaluated the effect of increasing MSG concentrations on rat thymocyte apoptosis. We showed that MSG, at concentrations ranging from $1 \mathrm{mM}$ to $100 \mathrm{mM}$, was able to trigger apoptosis of rat thymocytes, as determined by staining with Annexin-VFITC/PI (Fig. 1). The staining shows a significant dosedependent increase in the percentage of apoptotic cells in the total population over controls (Table 1). As shown in Figure 1 and Table 1, MSG significantly induced cell apoptosis as a consequence of induction of the late stage of thymocyte apoptosis (Annexin-V-FITC positive/PI positive cells).

\section{Effect of MSG on Bcl-2 and Bax levels}

Since our previous results demonstrated that in vitro treatment with $\mathrm{MSG}$ induced apoptosis of rat thymocytes, we studied the relationship between these phenomena and the expression of Bcl-2 and Bax proteins in rat thymocytes. The level of Bcl-2 and Bax in rat thymocytes was determined by flow cytometry, using cells cultured with increasing concentrations (1-100 mM) of MSG for $24 \mathrm{~h}$. As shown in Figure 2, MSG administration induced significant down-regulation of Bcl-2 protein in rat thymocyte cultures. No significant changes in the level of Bax protein in thymocyte cultures were detected at the end of incubation period (Fig. 2).

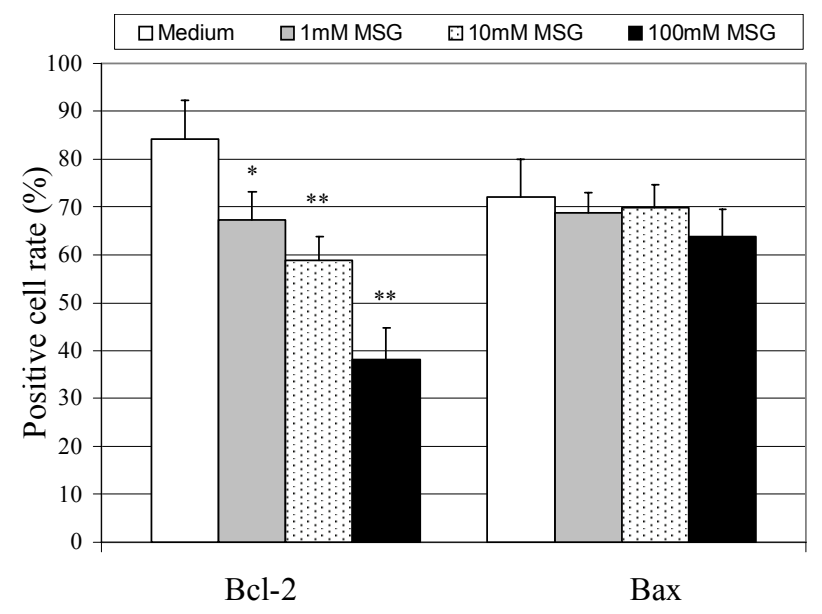

Fig. 2. Flow cytometric analysis of $\mathrm{BCl}-2$ and Bax levels in rat thymocytes treated with increasing concentrations of MSG. 


\section{Discussion}

Apoptosis or programmed cell death of developing thymocytes is an active signal-dependent process during which autoreactive or non-functional $\mathrm{T}$ cells are eliminated. This process occurs intrathymically during the process of differentiation and maturation of thymocytes (Savino and Dardenne 2000). Thymocytes develop in close apposition to the thymic stromal cells that provide specific microenvironmental signals able to sustain $\mathrm{T}$ cell proliferation and maturation (Storto et al. 2000). Various hormones, neuropeptides and neurotransmitters originating from neuroendocrine system, as well as those produced intrathymically, modulate intrathymic $\mathrm{T}$ cell differentiation, thymic cell proliferation and apoptosis (Savino and Dardenne 2000).

In the present study we showed that MSG was able to induce cytotoxicity in rat thymocyte cultures. By using Annexin V-FITC/PI staining, we have showed that the cells are dying via apoptotic mechanism as a result of the MSG-induced cell death. Obtained results support our hypothesis that MSG-induced cytotoxicity was a consequence of increased thymocyte apoptosis. The apoptosis rate of control cultures might be a consequence of rapid apoptosis of thymocytes in vitro. It is believed that such a spontaneous apoptosis of thymocytes is due to the absence of different survival factors provided in vivo by the thymic microenvironment, such as soluble factors and signals, generated through direct cell-cell contacts (Baumann et al. 2000). Furthermore, our findings demonstrate that the exposure to MSG resulted in significantly increased thymocyte apoptosis that was concentration-dependent. These findings correlated with a significant decrease in the proportion of viable cells in cultures, as determined by trypan blue exclusion test. Obtained results are in agreement with previous reports, which indicated that glutamate-induced cell death may be the result of apoptosis and necrosis (Martin et al. 2000, Schelman et al. 2004), depending on the severity of stimulation (Bonfoco et al. 1998). It is well known that interactions between thymocytes and stromal cells are essential for the development of both $\mathrm{T}$ cells precursors and thymus stroma (Ritter and Boyd 1993). Thymic epithelial cells are also a target for various neuropeptides and neurotransmitters that are implicated in intercellular communication (Savino and Dardenne 2000). Recent report has shown the existence of mGlu receptors on mouse thymic stromal cells and thymocytes, suggesting a possible role of these receptors in signaling within thymus (Storto et al. 2000). Rezzani et al. (2003) showed that mGlu5 receptors are strongly expressed in rat thymocytes. Activation of mGlu5 receptors produces increases in intracellular $\mathrm{Ca}^{2+}$ (Miglio et al. 2005), which activate a cascade of reactions that play a pivotal role in cell growth, differentiation and survival (Bootman et al. 2001). Taken together with our results, it appears that the activation of glutamate receptors has a role in the intrathymic lympho-stromal relationships, as well as in modulation of thymocyte functions. The immunological relevance of this modulation remains to be clarified, but we can presume that MSG may play a significant role in regulation of thymocyte survival and differentiation with important secondary immunological consequences.

The bcl-2 family of proto-oncogenes encodes specific proteins, which regulate programmed cell death under different physiological and pathological conditions (Antonsson and Martinou 2000). In the present study, we examined the temporal changes in the protein level of two important apoptosis-related genes (Bcl-2 and Bax) in rat thymocytes subjected to MSG treatment. Using flow cytometric analysis, we found that Bcl-2 protein level is significantly downregulated following increased MSG exposure, suggesting that $\mathrm{Bcl}-2$ protein plays an important role in MSG-initiated apoptosis in rat thymocytes. These observations are in accordance with the findings that glutamate decreases Bcl-2 protein level in different cell type (Peter et al. 1997), while Bcl-2 overexpression rescues cells from glutamate-induced apoptosis (Molto et al. 2003, Langenau et al. 2005). It has been demonstrated that apoptosis is modulated at least in part by the Bcl-2 family of proteins: apoptosisinhibiting gene products $\left(\mathrm{Bcl}-2, \mathrm{Bcl}-\mathrm{X}_{\mathrm{L}}, \mathrm{Mcl}-1, \mathrm{~A} 1\right.$, Bcl-w) and apoptosis-accelerating gene products (Bax, Bak, Bcl-X $\mathrm{X}_{\mathrm{S}}$ Bim) (Adams and Cory 1998). An important feature of the members of Bcl-2 family is their ability to form homo- as well heterodimers. The heterodimerization between proapoptotic and the antiapoptotic proteins such as $\mathrm{Bcl}-2 / \mathrm{Bax}$ dimerization may be a critical event in regulation of apoptotic cell death (Burlacu 2003). Recent reports showed that glutamate induced $\mathrm{Ca}^{2+}$ influx and disruption of the inner transmembrane potential of the mitochondria, which resulted in opening the mitochondria permeability transition pore (Kanki et al. 2004, Khodorov et al. 2002). When permeability transition pore is out of control, several essential players of apoptosis, including procaspases, cytochrome c, apoptosis-inducing factor and apoptosis protease-activating factor 1 (APAF-1) are 
released into the cytosol. They have the ability to activate caspases, which results in apoptosis (Desagher and Martinou 2000). Bcl-2 is localized on the cytoplasmatic face of the mitochondrial outer membrane, endoplasmatic reticulum and nuclear envelope. This protein maintains the membrane integrity of mitochondria by preventing the release of cytochrome $\mathrm{c}$ which, together with APAF-1, facilitates the activation of caspase 9 (Burlacu 2003). Bax can antagonize function of Bcl-2 protein through forming homodimers, which may liberate cytochrome c and start apoptotic process. Furthermore, Bax interacts with Bcl-2 to interfere with its ability to anchor APAF-1. Unbound APAF-1 cleaves procaspase 9 into active enzyme, which induces the programmed cell death (Adams and Cory 1998). In our study, the MSG-induced downregulation of Bcl-2 might disturb the control of permeability transition pore opening so that the caspase activating factors were released from mitochondria. These findings correlate with significant dose-dependent increase of cytotoxicity and thymocyte apoptosis. However, Bax protein levels were not significantly changed in our study. We propose that the $\mathrm{Bcl}-2 / \mathrm{Bax}$ ratio rather than the Bax level is the important determinant for the induction of apoptosis in thymocytes by MSG. Bax was found to be upregulated during apoptosis in several types of cells, together with the decrease of the Bcl-2 protein level (Peter et al. 1997). Furthermore, Bax deficiency has been reported to rescue the death of double positive thymocytes in Bcl-2deficient mice (Knudson and Korsmeter 1997). On the other hand, recent reports suggested that the levels of Bcl-2 and Bax may influence the sensitivity of cells to the mediators of programmed cell death (Schelman et al. 2004, Bladon and Taylor 2002, Almawi et al. 2004). It has been proposed that Bax/Bax homodimer is the dominant regulator of the cell death signal (Sedlack et al. 1995) and that the anti-death effect of Bcl-2 is due to its association with Bax, which results in the reduction of the free Bax pool for homodimerization.

In summary, we have shown that upon in vitro exposure to MSG rat thymocytes undergo cell death via an apoptotic mechanism. The temporal profile of Bcl-2 and Bax expression after MSG treatment suggests that downregulation of $\mathrm{Bcl}-2$ protein and resulting changes of Bcl-2/Bax protein ratio may be an important event in thymocyte apoptosis triggered by MSG. We are currently investigating the in vitro response of different thymocyte subsets to MSG exposure in order to determine the cellular basis of its action and signaling mechanisms involved.

\section{Acknowledgements}

This work was supported by the Ministry of Science and Environmental Protection of Serbia (Project 145081).

\section{References}

ADAMS JM, CORY S: The Bcl-2 protein family: arbiters of cell survival. Science 281: 1322-1326, 1998.

ALMAWI XY, MELEMEDJIAN OK, JAOUDE MM: On the link between Bcl-2 family proteins and glucocorticoidinduced apoptosis. J Leukoc Biol 76: 7-14, 2004.

ANKARCRONA M, DYPBUKT JM, BONFOCO E, ZHIVOTOVSKY B, ORRENIUS S, LIPTON SA, NICOTERA P: Glutamate-induced neuronal death: a succession of necrosis or apoptosis depending on mitochondrial function. Neuron 15: 961-973, 1998.

ANTONELLA A, DELIA D, BORRELLO MG, BIASSONI D, GIARDINI R, FONTANELLA E, PEZZELLA F, PULFORD K, PIEROTTI M, PORTA GD: Flow cytometric detection of the mitochondrial Bcl-2 protein in normal and neoplastic human lymphoid cells. Cytometry 13: 502-509, 1992.

ANTONSSON B, MARTINOU JC: The Bcl-2 protein family. Exp Cell Res 256: 50-57, 2000.

BAUMANN CA, BADAMCHIAN M, GOLDSTEIN AL: Thymosin alphal is a time- and dose-dependent antagonist of dexamethasone-induced apoptosis of murine thymocytes in vitro. Int J Immunopharmacol 22: 1057-1066, 2000 .

BLADON J, TAYLOR PC: Lymphocytes treated by extracorporeal photopheresis demonstrate a drop in the Bcl-2/Bax ratio: a possible mechanism involved in extracorporeal photopheresis-induced apoptosis. Dermatology 204: 104-107, 2002.

BOLDYREV AA, KAZEY VI, LEINSOO TA, MASKINA A, TYULINA O, JOHNSON P, TUNEVA JO, CHITTUR S, CARPENTER DO: Rodent lymphocytes express functionally active glutamate receptors. Biochem Biophys Res Commun 324: 133-139, 2004. 
BONFOCO E, KRAINC D, ANKARCRONA M, NICOTERIA P, LIPTON SA: Apoptosis and necrosis: two distinct events induced, respectively, by mild and intense insults with N-methyl-D-aspartate or nitric oxide/superoxide in cortical cell cultures. Proc Natl Acad Sci USA 92: 7162-7166, 1998.

BOOTMAN MD, LIPP P, BERRIDGE MJ: The organization and functions of local $\mathrm{Ca}^{2+}$ signals. J Cell Sci 114: 2213 2222, 2001.

BURLACU A: Regulation of apoptosis by Bcl-2 family proteins. J Cell Mol Med 7: 249-257, 2003.

CHOUDHARY P, MALIK VB, PURI S, AHLUWALIA P: Studies on the effects of monosodium glutamate on hepatic microsomal lipid peroxidation, calcium, ascorbic acid and glutathione and its dependent enzymes in adult male mice. Toxicol Lett 89: 71-76, 1996.

DESAGHER S, MARTINOU JC: Mitochondria as central control point of apoptosis. Trends Cell Biol 10: 369-377, 2000.

ERAY M, MATTO M, KAARTINEN M, ANDERSON L, PELKONEN J: Flow cytometric analysis of apoptotic subpopulations with a combination of annexin V-FITC, propidium iodide, and SYTO 17. Cytometry 43: 134$142,2001$.

GANOR Y, BESSER M, BEN-ZAKAY N, UNGER T, LEVITE M: Human T-cells express a functional ionotropic glutamate receptor GluR3, and glutamate by itself triggers integrin-mediated adhesion to laminin and fibronectin and chemotactic migration. J Immunol 170: 4362-4372, 2003.

GILL SS, PULIDO OM: Glutamate receptors in peripheral tissues: current knowledge, future research, and implications for toxicology. Toxicol Pathol 29: 208-223, 2001.

GILL SS, PULIDO OM, MUELLER RW, MCGUIRE PF: Immunochemical localization of the metabotropic glutamate receptors in the rat heart. Brain Res Bull 48: 143-146, 1999.

GILL SS, MUELLER RW, MCGUIRE PF, REFINED OM: Potential target sites in peripheral tissues for excitatory neurotransmission and excitotoxicity. Toxicol Pathol 28: 277-285, 2000.

HINOI E, TAKARADA T, UESHIMA T, TSUCHIHASHI Y, YONEDA Y: Glutamate signaling in peripheral tissues. Eur J Biochem 271: 1-13, 2004.

KANKI R, NAKAMIZO T, YAMASHITA H, KIHARA T, SAWADA H, UEMURA K, KAWAMATA J, SHIBASAKI H, AKAIKE A, SHIMOHAMA S: Effects of mitochondrial dysfunction on glutamate receptormediated neurotoxicity in cultured rat spinal motor neurons. Brain Res 1015: 73-81, 2004.

KHODOROV BI, STOROZHEVYKH TP, SURIN AM, YURYAVICHYUS AI, SOROKINA EG, BORODIN AV, VINSKAYA NP, KHASPEKOV LG, PINELIS VG: The leading role of mitochondrial depolarization in the mechanism of glutamate-induced disruptions in $\mathrm{Ca}^{2+}$ homeostasis. Neurosci Behav Physiol 32: 541-547, 2002.

KNUDSON CM, KORSMETER SJ: Bcl-2 and Bax function independently to regulate cell death. Nat Genet 16: 358363, 1997.

KOOPMAN G, REUTELINGSPERGER CP, KUIJTEN GA, KEEHNEN RM, PALS ST, VAN OERS MH: Annexin V for flow cytometric detection of phosphatidylserine expression on B cells undergoing apoptosis. Blood $\mathbf{8 4}$ : 1415-1420, 1994.

LANGENAU DM, JETTE C, BERGHMANS S, POLOMERO T, KANKI JP, KUTOK JK, LOOK AT: Suppression of apoptosis by bcl-2 overexpression in lymphoid cells of transgenic zebrafish. Blood 105: 3278-3285, 2005.

LECOEUR H, PREVOST MC, GOUGEON ML: Oncosis is associated with exposure of phosphatidylserine residues on the outside layer of the plasma membrane: a reconsideration of the specificity of the annexin V/propidium iodide assay. Cytometry 44: 65-72, 2001.

LIU X, ZHU XZ: Roles of p53, c-Myc, Bcl-2, Bax and caspases in glutamate-induced neuronal apoptosis and the possible neuroprotective mechanism of basic fibroblast growth factor. Mol Brain Res 71: 210-216, 1999.

LOMBARDI G, DISANZANI C, MIGLIO G, CANONICO PL, FANTOZZI R: Characterization of ionotropic glutamate receptors in human lymphocytes. Br J Pharmacol 133: 936-944, 2001.

LOMBARDI G, MIGLIO G, DIANZANI C, MESTURINI R, VARSALDI F, CHIOCCHETI A, DIANZANI U, FANTOZI R: Glutamate modulation of human lymphocyte growth: in vitro studies. Biochem Biophys Res Commun 318: 496-502, 2004. 
MARTIN LJ, SIEBER FE, TRAYSTMAN RJ: Apoptosis and necrosis occur in separate neuronal populations in hippocampus and cerebellum after ischemia and are associated with differential alterations in metabotropic glutamate receptor signaling pathways. J Cereb Blood Flow Metab 20: 153-167, 2000.

MIGLIO G, VARSALDI F, DIANZANI C, FANTOZZI R, LOMBARDI G: Stimulation of group I metabotropic glutamate receptors evokes calcium signals and c-jun and c-fos gene expression in human $\mathrm{T}$ cells. Biochem Pharmacol 70: 189-199, 2005.

MOLTO L, RAYMAN P, PASZKIEWICZ-KOZIK E, THORNTON M, REESE L, THOMAS JC, DAS T, KUDO D, BUKOWSKI R, DERWEESH I, TANNENBAUM CS, FINKE JH: The Bcl-2 transgene protects T cells from renal cell carcinoma-mediated apoptosis. Clin Cancer Res 9: 4060-4068, 2003.

OKASHA SA, RYU S, DO Y, MCKALLIP RJ, NAGARKATTI M, NAGARKATTI PS: Evidence for estradiolinduced apoptosis and dysregulated $T$ cell maturation in the thymus. Toxicology 163: 49-62, 2001.

PACHECO R, CIRUELA F, CASADO V, MALLOL J, GALLART T, LUIS C, FRANCO R: Group I metabotropic glutamate receptors mediate a dual role of glutamate in T-cell activation. J Biol Chem 279: 33352-33358, 2004.

PETER ME, HEUFELDER AE, HENGARTNER MO: Advances in apoptosis research. Proc Natl Acad Sci USA 94: 12736-12737, 1997.

REZZANI R, CORSETTI G, RODELLA L, ANGOSCINI P, LONATI P, BIANCHI R: Cyclosporine-A treatment inhibits the expression of metabotropic glutamate receptors in rat thymus. Acta Histochem 105: 81-87, 2003.

RITTER AM, BOYD LR: Development in the thymus: it takes two to tango. Immunol Today 14: 462-470, 1993.

SAVINO W, DARDENNE M: Neuroendocrine control of thymus physiology. Endocr Rev 21: 412-443, 2000.

SCHELMAN WR, ANDRES RD, SIPE KJ, KANG E, WEYHENMEYER JA: Glutamate mediates cell death and increases the Bax to Bcl-2 ratio in a differentiated neuronal cell line. Brain Res Mol Brain Res 128: 160-169, 2004.

SEDLACK TW, OLTVAI ZN, YANG E, WANG K, BOISE LH, THOMPSON CB, KORSMEYER SJ: Multiple Bcl-2 family members demonstrate selective dimerisations with Bax. Proc Natl Acad Sci USA 92: 7834-7838, 1995.

SKERRY TM, GENEVER PG: Glutamate signalling in non-neuronal tissues. Trends Pharmacol Sci 22: 174-181, 2001.

STORTO M, GRAZIA U, BATTAGLIA G, FELLI M, MARODER M, GULINO A, RAGONA G, NICOLETTI F, SCREPANTI I, FRATI L, CALOGERO A: Expression of metabotropic glutamate receptors in murine thymocytes and thymic stromal cells. J Neuroimmunol 109: 112-120, 2000.

STORTO M, SALLESE M, SALVATORE L, POULET R, CONDORELI DF, DELL'ALBANI P, MARCELLO MF, ROMEO R, PIOMBONI P, BARONE N, NICOLETTI F, DE BLASI A: Expression of metabotropic glutamate receptors in the rat and human testis. J Endocrinol 170: 71-78, 2001.

VERMES I, HAANEN C, STEFFENS-NAKKEN H, REUTELINGSPERGER C: A novel assay for apoptosis. Flow cytometric detection of phosphatidylserine expression on early apoptotic cells using fluorescein labelled Annexin V. J Immunol Methods 184: 39-51, 1995.

\section{Corresponding author}

Voja Pavlovic, Institute of Physiology, Medical Faculty, University of Nis, Bulevar dr Zorana Djindjića, 18000, Nis, Serbia. E-mail: vojapav@yahoo.com 